\title{
INFLUENCE OF OCCUPATIONAL HEALTH SAFETY (OHS) CULTURE, COMMITMENT MANAGEMENT, OHS TRAINING ON OHS PERFORMANCE IN OIL \& GAS CONTRACTORS COMPANY IN BATAM ISLAND
}

\author{
Alden Nelson ${ }^{1)}$, Yedin Arianto Zega ${ }^{2)}$ \\ 1,2,3) University of International Batam, Batam, Riau Islands, Indonesia \\ Corresponding author: alden.nelson@uib.ac.id
}

\begin{abstract}
Indonesia has very promising oil and gas potential to be exploited, including in Riau Islands province, which has 15 oil and gas companies operating, and 4 of them are already in production. Batam Island is part of the Kepulauan Riau province, and there are oil and gas fabrications in it that are exported out from Batam Island. This fabrication is closely related to occupational safety and health. This study was obtained from 261 employees who work in the fabrication company or oil and gas contractor. Data were processed using Statistical Package for Social Science (SPSS) version 24. The research of this method used non-probability sampling, where sampling techniques do not provide equal opportunities for each member of the population to be selected as a sample. This study illustrated that OHS culture and management commitment significantly positively affect occupational health safety performance, but OHS training does not have a significant effect.
\end{abstract}

Keywords: OHS Culture, Commitment Management, OHS training, and OHS Performance

\section{Introduction}

Gross Domestic Product (GDP) is a measure of the economy in Indonesia. In 2019, the base price in effect was Rp. 15833.9 trillion and for per capita GDP is Rp. 59.1 million or the US \$ 4 174.9. This shows that the Indonesian economy in 2019 grew by 5.02 percent, although it was lower than in 2018 , with a value of 5.17 percent. This national economic growth also includes the export value of several provinces in Indonesia, including the Riau Islands province, an oil and gas export value (BPS Kepulauan Riau). The export data in Riau Islands Province in January 2020, with an export value of US \$1,043.97 million, decreased by 4.78 percent compared to the export value in December 2019. The data referred t includes the export of oil and gas specifically for the Riau Islands province in January 2020, amounting to the US \$ 243.10 million or still decreased by 17.43 percent compared to the value of exports in December 2019. Based on statistical data, it is not only the oil and gas sector that has decreased but non-oil and gas exports in January 2020, which reached the US \$ 800.87 million or decreased 0, 14 percent compared to December 2019 (BPS Kepulauan Riau Province). One area is included in the Riau Islands province and has an industry that supports oil and gas exports is Batam Island. On this island, there are several oil and gas fabrications. In fabricating oil and gas equipment, occupational safety and health are important because it relates to the costs of accidents, which include financial losses, lost time, property damage, insurance premiums, and overtime costs and costs. Training, loss of prestige, lost company relationships, decreased quality, and loss of profits are called indirect costs (Bayram et al., 2017).

Safety first is the main critical thing that can be seen in a safety organization because it is a significant problem in many safety organizations themselves critically. Based on the report on yearly basis show thousands of employees die at the workplace, and millions suffer from occupational injuries and illnesses (Siu et al. 2004; Cigularov et al., 2010) in safety organizations such as manufacturing, construction, oil and gas, and mining (Al-haadir et al., 2013). This shows that safety is essential (Salleh \& Memon, 2014). To improve occupational health safety performance and prevent work accidents in Indonesia, especially in Batam Island, Law Number 1 of 1970 concerning Occupational Health Safety shall be fully implemented. In practice, for the intended Law to be fully implemented, law Number 13 of 2003 concerning Manpower is also applied. The implementation and application of both laws are aimed to reduce the number of accidents through the application of Occupational Health and Safety (OHS). Occupational health and safety itself is a safe condition from the things which can cause or suffer injuries or losses that might occur (Maguire, 2006:3).

Safety compliance and safety participation are essential aspects in occupational health and safety performance (Inness Michelle et al., 2010). Safety compliance has several parts, including carrying out safety procedures and working safely. Meanwhile, parts of safety participation are helping colleagues, having initiative at work, and improving safety and security in the workplace (Cai, 2005). Since the industrial revolution was known from 1799 (Renald Kasali, 2018) till the industrial era 4.0, in detail according to Klaus Schwab (2017) where this era began in the late 18th (eighteenth) century known as mechanization, hydropower, and steam power. Along with advances in information technology, the performance of occupational health and safety in industries has become the primary concern. The construction industry faces various accidents, incidents, or hazards in the workplace (Tengilimoglu et al., 2016). 
The statement from Minister of Manpower of the Republic of Indonesia in daily tempo.com, dated January 12, 2020, said: "Today, innovation, automation, supercomputers, artificial intelligence and flexibility in work patterns have brought economic changes to the digital-based. With the industrial revolution 4.0 based on information technology, do not let OHS problems have pay attention when the victims fall when victims fall, or accidents happen. Do not let us care about OHS when there is a lawsuit from the community or the families of the victims "(Ida Fauziah, Minister of Manpower of the Republic of Indonesia, 2020. Tempo.com). As we know, there have been 157,313 work accident cases in 2018, and from January to September 2019, there have been 130,923 cases, which shows that there has been a decrease in work accident cases by $26.40 \%$ Ananda (, 2020). Of course, reducing work accidents is a significant concern that we must do in preventing work accidents from ensuring the employees can work safely.

\section{Literature Review \\ Occupational Health Safety Culture}

In the fabrication and exploration of the oil and gas industry, the safety culture or OHS culture plays an important role. Oil and gas workers realize that what is no less important is the availability of place and time to communicate about OHS issues (Hong et al., 2018). Communication is part of a safety culture; when a work accident occurs, communication is needed. Communication can prevent workplace accidents; as mentioned in several previous studies, communication from safety culture is essential because it can increase KPI (Key Performance Indicator) and the opposite.

Culture is a habit that is a fundamental way of thinking where group studies and uses it to solve problems with external and internal approaches that are strong and helpful so that people in a group accept it and feel there is a relationship to problems which are solved by that habit (Schein, 2010; Helen Lingard et al. (2017). OHS culture is a habit that thinks safety at work is the main thing. Work shall be done with good habits such as not being willing to work before the OHS meeting first or known as toolbox talk safety meeting.

\section{Management Commitment}

Management commitment is the foundation of an effective safety management system (Latief et al., 2017). Previous studies have described that one of the factors affecting occupational safety and health is the management commitment from a company. Top management's policies will be very easily understood by subordinates and carried out because there is a commitment from the management to obey them, and work accidents can be avoided in the workplace. Based on daily activities, commitment, awareness, communication, and supervision from top management are management commitment scope (Sarkam et al., 2018).

Previous research using management commitment variables affects OHS performance in terms of safety compliance and safety participation (Hong et al., (2018). This research shows that the management committed to OHS shall make every effort through internal control, resources, and practice it then the employees feel it. According to Khdair (2011), this variable states that leadership as part of management commitment has a positive effect on OHS performance. Another researcher, Chen et al., (2018), explained that management commitment needs a development time frame and that differences in concepts, beliefs, and values affect OHS performance effectively. Another researcher, Sarkam et al. (2018), explained a significant positive relationship between OHS performance and management commitment. This variable is also used by Romuty (2017) with the results of research which explains that safety leadership as part of management commitment, Chong (2018) has a significant positive effect on the OHS performance variables.

\section{Occupational Health Safety Training}

OHS training is an essential element of an OHS management system; the training is conducted to increase the awareness of potential hazards and risks (Chong, 2018). OHS training is also a branch of psychology called educational psychology, where the learning and education process is studied (McGraw, 1953). A person who works in the oil and gas world can only reduce work accidents by fulfilling the OHS requirements by attending various safety training. Workers who are attending the training will have more knowledge on OHS and proficiency in preventing workplace accidents. According to Law No. 1, the year 1970 concerning Occupational Safety and Health, companies must provide instructions, training, and supervision necessary to ensure the safety and health of workers/ laborers.

The OHS training will affect OHS performance in oil and gas fabrication, as seen from the key performance indicator (KPI) written in company statistics. Workers in oil and gas fabrication can identify hazards, assess risks and determine controls because the workers have been trained. Participation in OHS (safety participation) through training obtained in the OHS training program within the company and this implementation is carried out before undertaking an oil and gas project. OHS analysis is known as the Job Safety Analysis (JSA), aims to reduce workplace accidents. Workers doing work already know the dangers of the work and are carried out safely because of JSA. This affects OHS performance by reducing the number of work accidents. Conduct safety training in the workplace and comply with OHS requirements (safety compliance) and labor laws. 


\section{Conceptual Framework}

Based on the explanation above, the conceptual framework proposes as below figure 1 to show the OHS performance as below :

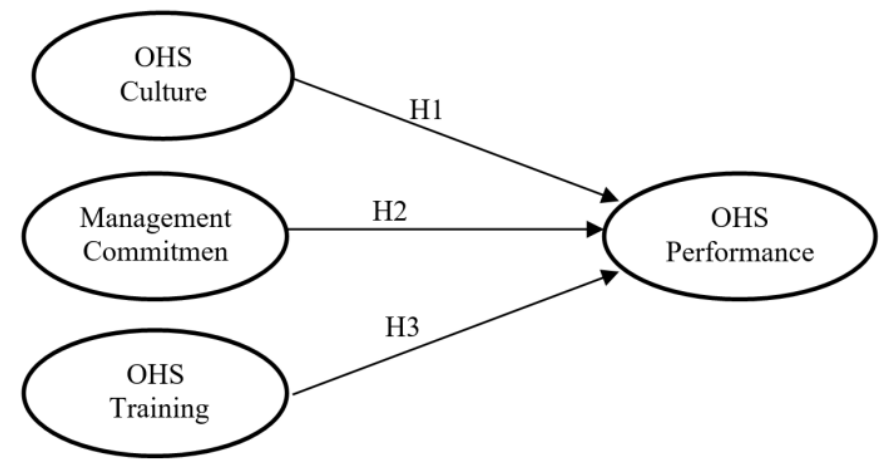

Figure 1. Research Framework

The hypothesis is a temporary answer to the formulation of the research problem, where the formulation of the research problem has been stated in the form of a question sentence. In this study, there are three hypotheses proposed, and the truth is still to be tested. Based on the research model described above, the following hypothesis is formulated:

H1: OHS Culture has a significant effect on OHS Performance.

$\mathrm{H} 2$ : Management commitment has a significant effect on OHS Performance.

H3: OHS training has a significant effect on OHS Performance.

\section{Research Method}

The population in this study were employees who worked at oil and gas companies in Batam Island, both onshore and offshore. The fabrication company or oil and gas contractor, such as PT. McDermott Indonesia, PT. Citra Tubindo Engineering, PT. Dwi Sumber Arca Waja (DSAW) and several oil and gas fabrication companies onshore and offshore in Batam Island with 261 respondents.

The questionnaire consists of 28 statements containing descriptive statistical values using a scale of 1 to 5 , and the data will be analyzed using SPSS version 24.

Determination of data sources in this study was carried out using non-probability sampling, which did not provide equal opportunities to members of the population to be selected as samples Sugiyono (, 2017). This sampling technique is carried out by purposive sampling method, which means that it is carried out with specific considerations; in this case, the researcher considers only people who work in the oil and gas industry with expertise in this industry are determined to be the source of the data.

OHS performance is the dependent variable in this study. OHS performance plays a significant role in determining a company's reputation or business because it is one of the critical performance indicators sold to prospective clients. Previous research has described occupational safety and health, which is predicted to affect OHS performance itself. OHS performance can also be likened to what is done by workers in the workplace, and this is included as part of safety compliance and safety participation (Gao et al., 2016).

\section{Result and Discussion}

Table 1. Validity test result

\begin{tabular}{|c|c|c|}
\hline Variable & Loading Vactor & Kesimpulan \\
\hline OHS culture 1 & 0,801 & Valid \\
\hline OHS culture 2 & 0,823 & Valid \\
\hline OHS culture 3 & 0,852 & Valid \\
\hline OHS culture 4 & 0,859 & Valid \\
\hline Management commitment 1 & 0,805 & Valid \\
\hline Management commitment 2 & 0,792 & Valid \\
\hline Management commitment 3 & 0,644 & Valid \\
\hline Management commitment 4 & 0,757 & Valid \\
\hline Management commitment 5 & 0,794 & Valid \\
\hline Management commitment 6 & 0,830 & Valid \\
\hline Management commitment 7 & 0,730 & Valid \\
\hline Management commitment 8 & 0,820 & Valid \\
\hline Management commitment 9 & 0,803 & Valid \\
\hline Management commitment 10 & 0,812 & Valid \\
\hline OHS training 1 & 0,829 & Valid \\
\hline
\end{tabular}




\begin{tabular}{lcc}
\hline OHS training 2 & 0,890 & Valid \\
OHS training 3 & 0,855 & Valid \\
OHS training 4 & 0,839 & Valid \\
OHS training 5 & 0,823 & Valid \\
OHS training 6 & 0,758 & Valid \\
OHS training 7 & 0,858 & Valid \\
OHS training 8 & 0,750 & Valid \\
OHS performance 1 & 0,863 & Valid \\
OHS performance 2 & 0,904 & Valid \\
OHS performance 3 & 0,892 & Valid \\
OHS performance 4 & 0,834 & Valid \\
OHS performance 5 & 0,901 & Valid \\
OHS performance 6 & 0,869 & Valid \\
\hline
\end{tabular}

Based on the data in table 1 shown all variables are valid because the loading factor $>0.6$ (Ghozali, 2011; Hair et al., 2009) and the reliability test for all variables also are valid because the Cronbach's Alpha $\geq$ 0.6 (Hair et al., 2011: 92) as shown in table 2.

Table 2. Reliability test result

\begin{tabular}{llll}
\hline \multicolumn{1}{c}{ Variable } & & \multicolumn{1}{c}{ Cronbach's Alpha } & \\
\cline { 2 - 3 } OHS culture & 0,853 & Reliable \\
Management Commitment & 0.924 & Reliable \\
OHS training & 0.933 & Reliable \\
OHS performance & 0.836 & Reliable \\
\hline
\end{tabular}

\section{Linearity Test}

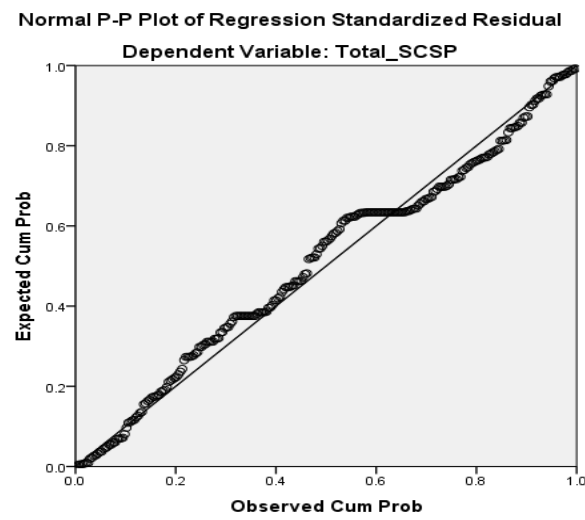

Figure 2. P-P Plot Normality Test Results

Based on Figure 2 above, it is clear that the Normal P-P Plot chart dependent variable occupational health and safety performance provides information about the normal distribution. This is known by observing that the distribution data from bottom to top always follows a diagonal line. This description is evidence that the occupational health safety performance has a normal distribution.

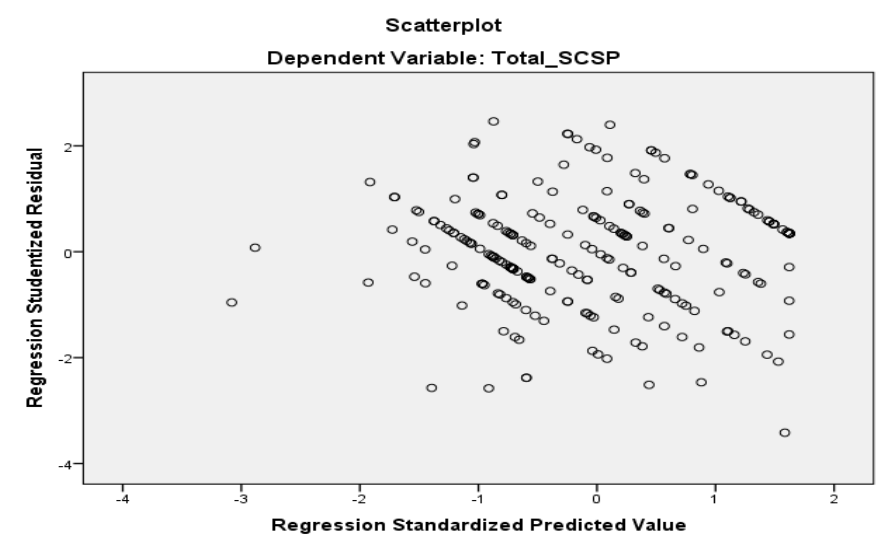

Figure 3. Heteroscedasticity test result 
The distribution data in figure 3 above shows the points spread randomly. There is no particular shape or pattern so that it can be concluded there is no heteroscedastic symptom or visually the assumption of homoscedasticity is fulfilled in that model.

\section{Hypothesis Test}

This research describes the hypothesis test results using multiple regressions, which consists of the results of the $\mathrm{F}$ test, the t-test results, and the coefficient of determination test results. The results of the $\mathrm{F}$ test can be explained in table 3 below:

Table 3. F test result

\begin{tabular}{lccc}
\hline Variable & F & Sig. & Remarks \\
\hline OHS Performance & 155.857 & 0.000 & Significant \\
\hline
\end{tabular}

In table 3 above, the results of the $\mathrm{F}$ test obtained a probability level of 0.000 . Based on this information with $0.000<0.05$, this research model can predict the dependent variable (occupational health safety performance). Another part of the hypothesis test results is the t-test, where each independent variable is used to see the level of significance of the affected variable. The results of the test can be seen in Table 4 below:

Table 4. T-test results.

\begin{tabular}{|c|c|c|c|c|c|}
\hline Variable & $\begin{array}{l}\text { Unstandardized } \\
\text { Coefficients (B) }\end{array}$ & $\begin{array}{c}\text { Standardized } \\
\text { Coefficients } \\
\text { Beta }\end{array}$ & $\mathbf{t}$ & Sig. & Remarks \\
\hline (Constant) & 4.687 & & 4.584 & 0.000 & Significant \\
\hline OHS culture & 0.279 & 0.196 & 3.953 & 0.000 & Significant \\
\hline Management Commitment & 0.353 & 0.613 & 11.169 & 0.000 & Significant \\
\hline OHS Training & 0.039 & 0.073 & 1.459 & 0.146 & Not Significant \\
\hline
\end{tabular}

The t-test results above show that the significance level of the relationship between OHS culture and occupational health safety performance is smaller than the value of $0.05(0.000)$. The result concluded that there is a significant effect of safety culture on occupational health safety performance. The results of this study are consistent with previous studies conducted by Chen et al. (2018); Morrow et al. (2014); Tengilimoglu et al. (2016), Barnes (2014); Alolah Steward, Panuwatwnich \& Mohamed (2013); Zina, Ramalub, Hassana (2016); Memon et al., (2019); Christian et al., (2012), but inconsistent with (Hong et al., 2018).

Table 4 above shows that management commitment as an independent variable has a significant effect on occupational health safety performance. This is indicated with a value less than $0.05(0.000)$. The results of this study are consistent with the results of previous studies, including Chong et al. (2018), Gao et al. (2016); Christina et al. (2012); Singh et al. (2018), Khdair, Shamsudin, and Subramanim (2011); Sarkam Shaharuddin, Zaki, Maskdek (2018); Romuty, Chandra (1017); but inconsistent with Chen et al., (2018), Zina et al., (2016), Rafidah, et al. (2014).

The data processing results in table 4 above show one of the independent variables has a value greater than 0.05 (0.000), with a value of 0.146 . The independent variable is OHS training means the OHS training variable does not have a significant effect on occupational health safety performance. The results of this study are consistent with the results from previous research conducted by Subramaniam (2016). The other result studies which state that OHS training does not affect OHS performance are Chen et., Al (2018); Chong et., Al (2018), but it is different with Alolah et al. (2014) which the result is inconsistent because, according to his research, OHS training affects OHS performance. Another researcher who said the OHS training affects OHS performance is Mash et., Al (2016). According to this researcher, OHS training has a positive effect on OHS performance. Other researchers who explain that OHS affects OHS performance are Mash, Subramaniam, Johari (2016); Zina, Ramalub, Hassana (2016).

Observing the three independent variables above, it is clear the commitment management has the most outstanding contribution to improving the OHS performance with a value of 0.353 or $35.3 \%$, followed by OHS culture with a value of $0.27927 .9 \%$. The lowest value is the OHS training variable, with a value of 0.039 or $03.9 \%$. Therefore, the standard coefficient can be concluded that every time there is an increase in the value per unit in commitment management, it will increase the work health safety performance by 0.613 , each increase in the value per unit in the safety culture of 0.196 on the performance of occupational health safety. The safety training variable did not show an increase in occupational health safety performance in this study. Understanding of this process, the standard coefficient shows consistent results where management commitment has a significant influence, namely 0.613 . 
The coefficient of determination test is one part of the results of hypothesis testing, and the results of the coefficient of determination can be seen in the information in table 5 below. The results of the Adjusted R2 test below illustrated that the independent variable such as OHS culture, management commitment, and OHS training affected the dependent variable OHS performance of $64.1 \%$. In comparison, the remaining $35.9 \%$ is influenced by other variables.

Table 5. Coefficient of Determination result (R2)

\begin{tabular}{ccc}
\hline Variable & $\mathbf{R}$ & Adjusted $\mathbf{R 2}$ \\
\hline OHS Performance & 0.803 & 0.641 \\
\hline
\end{tabular}

\section{Conclusion}

The results of this study were conducted based on the phenomena that occur in oil and gas fabrication companies related to the performance of occupational health and safety. The problem of occupational health and safety has been formulated, so the research aims to find out the answers to the problems of the factors that affect occupational health and safety in oil and gas fabrication companies in Batam Island. The results of this study can be concluded that commitment management and OHS culture have a significant positive effect. However, it is different with the independent variable OHS training does not significantly affect OHS performance. Researchers suggest that the following researchers focus on other variables that can affect OHS performance in oil and gas fabrication companies.

\section{References}

Al-Refaie, A. (2013). Factors affect companies' safety performance in Jordan using structural equation modeling. Safety Science, 57, 169-178. https://doi.org/10.1016/j.ssci.2013.02.010

Ali Memon, D., Yusof, Y., Fauzi Ahmad, M., Raja, P., Pahat Johor, B., Anbia Adam, M., Ali Mangi, S., \& Adam, A. (2019). Theoretical Framework for Safety Culture and Safety Performance in Manufacturing Industries. International Journal of Mechanical Engineering and Technology (IJMET), 10(06), 176-186. http://www.iaeme.com/IJMET/index.asp176http://www.iaeme.com/ijmet/issues.asp?JType=IJMET\&VT ype=10\&IType=6http://www.iaeme.com/IJMET/index.asp177editor@ iaeme.comhttp://www.iaeme.com/ IJMET/issues.asp?JType $=$ IJMET $\&$ VType $=10 \&$ IType $=6$

Alolah, T., Stewart, R. A., Panuwatwanich, K., \& Mohamed, S. (2014). Developing a comprehensive safety performance evaluation framework for Saudi schools. In International Journal of Productivity and Performance Management (Vol. 63, Issue 4). https://doi.org/10.1108/IJPPM-05-2013-0096

Althaqafi, T., \& Abunar, S. (2017). Stakeholder Role in Safety Culture and Safety. Journal, Global Resource, Human Vol, Management Centre, European Uk, Development, 5(6), 36-48.

Ananda, P. (2020). Menaker Canangkan Bulan K3 Nasional Tahun 2020. Media Indonesia. https://mediaindonesia.com/read/detail/282866-menaker-canangkan-bulan-k3-nasional- ahun-2020

Bayram, M., Ünğan, M. C., \& Ardıç, K. (2017). The relationships between OHS prevention costs, safety performance, employee satisfaction and accident costs. International Journal of Occupational Safety and Ergonomics, 23(2), 285-296. https://doi.org/10.1080/10803548.2016.1226607

Cai, W. (2005). The Impact of Safety Culture on Safety Performance : a Case Study of a Construction Company. September, 301.

Cantor, D. E., Corsi, T. M., \& Grimm, C. M. (2017). The impact of new entrants and the new entrant program on motor carrier safety performance. Transportation Research Part E: Logistics and Transportation Review, 97, 217-227. https://doi.org/10.1016/j.tre.2016.11.005

Chen, Y., McCabe, B., \& Hyatt, D. (2018). A resilience safety climate model predicting construction safety performance. Safety Science, 109(July), 434-445. https://doi.org/10.1016/j.ssci.2018.07.003

Christina, W. Y., Ludfi, D., \& Thoyib, A. (2012). Pengaruh Budaya Keselamatan Dan Kesehatan Kerja ( K3 ) Terhadap Kinerja Proyek Konstruksi. Jurnal Rekayasa Sipil, 6(1), 83-95.

DeArmond, S., Bass, B. I., Cigularov, K. P., Chen, P., \& Moore, J. T. (2018). Leadership and safety: the role of goal commitment. Journal of Organizational Effectiveness, 5(2), 182-198. https://doi.org/10.1108/JOEPP-07-2017-0066

Donovan, S. L., Salmon, P. M., \& Lenné, M. G. (2016). Leading with style: a literature review of the influence of safety leadership on performance and outcomes. Theoretical Issues in Ergonomics Science, 17(4), 423-442. https://doi.org/10.1080/1463922X.2016.1143986

Enshassi, A., El-Rayyes, Y., \& Alkilani, S. (2015). Job stress, job burnout and safety performance in the palestinian construction industry. Journal of Financial Management of Property and Construction, 20(2), 170-187. https://doi.org/10.1108/JFMPC-01-2015-0004

Gao, R., Chan, A. P. C., Utama, W. P., \& Zahoor, H. (2016). Multilevel safety climate and safety performance in the construction industry: Development and validation of a top-down mechanism. International Journal of Environmental Research and Public Health, 13(11). https://doi.org/10.3390/ijerph13111100 
Ghasemi, F., Mohammadfam, I., Soltanian, A. R., Mahmoudi, S., \& Zarei, E. (2015). Surprising incentive: An instrument for promoting safety performance of construction employees. Safety and Health at Work, 6(3), 227-232. https://doi.org/10.1016/j.shaw.2015.02.006

Griffin, M. A., \& Hu, X. (2013). How leaders differentially motivate safety compliance and safety participation: The role of monitoring, inspiring, and learning. Safety Science, 60, 196-202. https://doi.org/10.1016/j.ssci.2013.07.019

Hee, O. C., \& Ping, L. L. (2014). Organizational Culture and Safety Performance in the Manufacturing Companies in Malaysia: A Conceptual Analysis. International Journal of Academic Research in Business and Social Sciences, 4(1), 99-108. https://doi.org/10.6007/IJARBSS/v4-i1/516

Hong, C. C., Ramayah, T., \& Subramaniam, C. (2018). The relationship between critical success factors, internal control and safety performance in the Malaysian manufacturing sector. Safety Science, 104(January), 179-188. https://doi.org/10.1016/j.ssci.2018.01.002

Inness Michelle, M., Turner, N., Barling, J., \& Stride, C. B. (2010). Transformational Leadership and Employee Safety Performance: A Within-Person, Between-Jobs Design. Journal of Occupational Health Psychology, 15(3), 279-290. https://doi.org/10.1037/a0019380

Ismail, U.-F. F. (2015). The Impact of Safety Climate on Safety Performance in a Gold Mining Company in Ghana. International Journal of Management Excellence, 5(1), 556. https://doi.org/10.17722/ijme.v5i1.194

Keffane (s), S. (2014). Communication's Role in Safety Management and Performance for the Road Safety Practices. International Journal of Transportation Science and Technology, 3(1), 79-94. https://doi.org/10.1260/2046-0430.3.1.79

Khdair, W. a. (2011). Improving Safety Performance By Understanding Relationship Between Management Practices and Leadership Behavior in the Oil and Gas Industry in Iraq: a Proposed Model. 2011 International Conference on Management and Artificial Intelligence, 6, 85-93.

Ko, Y. K., Jeong, S. H., \& Yu, S. (2018). Job autonomy, perceptions of organizational policy, and the safety performance of nurses. International Journal of Nursing Practice, 24(6), 1-7. https://doi.org/10.1111/ijn.12696

Latief, Y., Machfudiyanto, R. A., Arifuddin, R., Setiawan, R. M. F., \& Yogiswara, Y. (2017). Study of Evaluation OSH Management System Policy Based on Safety Culture Dimensions in Construction Project. Journal of Physics: Conference Series, 877(1). https://doi.org/10.1088/1742-6596/877/1/012028

Lun, C. J., \& Wahab, S. R. A. (2017). The Effects of Safety Leadership on Safety Performance in Malaysia . Saudi Journal of Business and Management Studies, 2(1), 12-18. https://doi.org/10.21276/sjbms.2017.2.1.3

Martínez-Córcoles, M., \& Stephanou, K. (2017). Linking active transactional leadership and safety performance in military operations. Safety Science, 96, 93-101. https://doi.org/10.1016/j.ssci.2017.03.013

Morrow, S. L., Kenneth Koves, G., \& Barnes, V. E. (2014). Exploring the relationship between safety culture and safety performance in U.S. nuclear power operations. Safety Science, 69, 37-47. https://doi.org/10.1016/j.ssci.2014.02.022

Mullen, J., Kelloway, E. K., \& Teed, M. (2017). Employer safety obligations, transformational leadership and their interactive effects on employee safety performance. Safety Science, 91, 405-412. https://doi.org/10.1016/j.ssci.2016.09.007

Nadhim, E. A., Hon, C., Xia, B., Stewart, I., \& Fang, D. (2018). Investigating the relationships between safety climate and safety performance indicators in retrofitting works. Construction Economics and Building, 18(2), 110-129. https://doi.org/10.5130/AJCEB.v18i2.5994

Purang, P. (2018). Role of Cultural Dimensions in Safety Performance of Global Oil and Gas Industry. Recent Advances in Petrochemical Science, 5(1). https://doi.org/10.19080/rapsci.2018.05.555653

R. Kaufman and, B., P. Cigularov, K., Chen, P., Hoffmeister, K., M. Gibbons, A., \& K. Johnson, S. (2014). Interactive effects of leader justice and support for safety on safety performance. Journal of Organizational Effectiveness, 1(3), 296-315. https://doi.org/10.1108/JOEPP-05-2014-0023

Rollah, S., Wahab, A., \& Shuen, Y. S. (2016). the Relationship Between Safety Communication and Human Factor Accident At the Workplace - a Conceptual Framework. Jurnal Kemanusiaan, 14(3), 1-4.

Romuty, Y. V. (2017). Model Pengaruh Safety Management Dan Safety Leadership Terhadap Safety Performance Pada Proyek Konstruksi Di Surabaya. Dimensi Utama Teknik Sipil, 4(1), 48-55. https://doi.org/10.9744/duts.4.1.48-55

Rostami, A., Sommerville, J., Wong, L. I., \& Lee, C. (2015). Engineering, Construction, and Architectural Management Article information : Engineering, Construction, and Architectural Management, 22(1), 91107. https://doi.org/http://dx.doi.org/10.1108/09699981111098711 Downloaded

Salleh, R., \& Memon, M. A. (2014). The Relationship of Safety Communication, LMX, and Safety Commitment: Conceptual Model. Australian Journal of Basic and Applied Sciences, September, 169174.

Sarkam, S. F., Shaharuddin, L. S., Zaki, B. M., Masdek, N. R. N. M., Yaacob, N. J. A., \& Mustapha, M. (2018). Factors Influencing Safety Performance at the Construction Site. International Journal of 
Academic Research in Business and Social Sciences, 8(9), 1057-1068. https://doi.org/10.6007/ijarbss/v8-i9/4680

Shehu, M., Subramaniam, C., \& Johari, J. (2016). The effect of safety training and workers involvement on healthcare workers safety behavior: the moderating role of consideration of future safety consequences. International Journal of Business Management, 1(2), 46-81.

Singh, V., \& Verma, A. (2019). Influence of respondent type on relationships between safety climate and safety performance in the manufacturing firm. Proceedings of the Institution of Mechanical Engineers, Part O: Journal of Risk and Reliability, 233(2), 268-284. https://doi.org/10.1177/1748006X18780773

Statistics of Kepulauan Riau Province. (n.d.). Ekspor Kepulauan Riau Bulan Januari 2020 turun 4,78 persen. https://kepri.bps.go.id/pressrelease/2020/02/17/1203/ekspor-kepulauan-riau-bulan-januari-2020-turun-478-persen.html

Subramaniam, C. (2016). Safety Management Practices and Safety Compliance: A Model for SMEs in Malaysia. 2013(2015), 856-862. https://doi.org/10.15405/epsbs.2016.08.120

Tarudin, N. F., Kordi, N. E., Aziz, T. N. A. T., \& Adlan, M. A. A. (2018). The inclination of oil and gas supply base personnel towards safety compliance. AIP Conference Proceedings, 2020(2018). https://doi.org/10.1063/1.5062678

Tengilimoglu, D., Celik, E., \& Guzel, A. (2016). The Effect of Safety Culture on Safety Performance: Intermediary Role of Job Satisfaction. British Journal of Economics, Management \& Trade, 15(3), 1-12. https://doi.org/10.9734/bjemt/2016/29975

Wu, T. C., Chen, C. H., \& Li, C. C. (2008). A correlation among safety leadership, safety climate, and safety performance. Journal of Loss Prevention in the Process Industries, 21(3), 307-318. https://doi.org/10.1016/j.jlp.2007.11.001

Yang, C.-C., Wang, Y.-S., Chang, S.-T., Guo, S.-E., \& Huang, M.-F. (2009). A study on the leadership behavior, safety culture, and safety performance of the healthcare industry. World Academy of Science, Engineering and Technology, 53(1), 1148-1155.

Zahoor, H., Chan, A. P. C., Utama, W. P., Gao, R., \& Zafar, I. (2017). Modeling the relationship between safety climate and safety performance in developing construction industry: A cross-cultural validation study. International Journal of Environmental Research and Public Health, 14(4). https://doi.org/10.3390/ijerph14040351 